
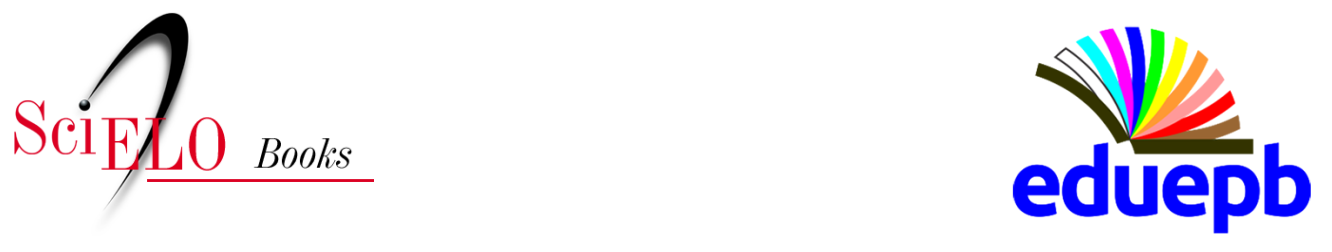

\title{
Escavando o Território da Análise de Discurso
}

\author{
Antonio Roberto Faustino da Costa
}

\section{SciELO Books / SciELO Livros / SciELO Libros}

COSTA, A. R. F. Escavando o Território da Análise de Discurso. In:

Industrialização do ensino e política de educação a distância [online].

Campina Grande: EDUEPB, 2019, pp. 101-152. Ensino e aprendizagem collection, vol. 4. ISBN: 978-85-7879-350-0.

https://doi.org/10.7476/9788578793500.0004.

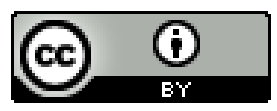

All the contents of this work, except where otherwise noted, is licensed under a Creative Commons Attribution 4.0 International license.

Todo o conteúdo deste trabalho, exceto quando houver ressalva, é publicado sob a licença Creative Commons Atribição 4.0.

Todo el contenido de esta obra, excepto donde se indique lo contrario, está bajo licencia de la licencia Creative Commons Reconocimento 4.0. 


\section{ESCAVANDO O TERRITÓRIO DA ANÁLISE DE DISCURSO}

Neste capítulo, visando responder à complexidade do fenômeno em estudo, articulando-o aos objetivos, à problemática e às questões da pesquisa, como forma de sustentar a tese aqui delineada, adentraremos ao território da Análise de Discurso (AD) de orientação francesa. Sobretudo porque permite esta compreender o discurso como um modo crítico de pensar, constituído pela "memória do dizer", que autoriza intervir o contexto histórico-ideológico, em condições de produção e situações de enunciação específicas, numa dada conjuntura social. Ao elegermos metodologicamente a AD como dispositivo analítico, somos tentados a postular, a priori, que o discurso da política nacional de educação a distância - como todo discurso - não seria transparente, mas atravessado por discursividades que se repetem, a partir de novas formulações, novas condições de produção, constituindo efeitos de sentidos como resultado de confrontos, conflitos e jogos, cuja forma e funcionamento mantêm conexão com as ideologias que estiverem circulando no tecido social.

Percorrendo as fundações desse território pantanoso, em que se encontram atalhos, vestígios e inflexões, é possível trazer à superfície as condições e as particularidades 
da emergência geográfica e temporal da $\mathrm{AD}$ e sua estabilização em contextos diferenciados, vendo que a memória discursiva se atualiza em lugares multifacetados, sem perder de vista o movimento da história. A AD surge como um campo de conhecimento que se desenvolve na França, entre as décadas de 1960 e 1970, tomando como referência e tentando levar a linguística herrisiana até as últimas consequências (PÊCHEUX et al, 1990, p.255). Já em 1952, no trabalho "Discourse Analysis: a sample text", o lingüista americano Z. S. Harris, retomado por Mazière (2007, p.7), definia a Análise de Discurso como dando conta - contrariamente à lingüística descritiva preocupada com os elementos da frase - de "uma multiplicidade de ensinamentos sobre a estrutura de um texto ou de um tipo de texto, ou sobre o papel de cada elemento nessa estrutura."

Não concebendo esses ensinamentos como estanques, representa a $\mathrm{AD}$ de orientação francesa um processo, isto é, "mais um movimento crítico que uma escola fornecendo categorias operatórias e métodos a aplicar." (MAZIÈRE, 2007, p.95) Dessa forma, constitui um método de compreensão de uma multiplicidade de objetos, segundo o qual não se trabalha a linguagem enquanto dado, mas como fato, tendo a sua origem vinculada ao político, o que a torna ponto de partida para compreendermos as formas textuais de sua representação. Em suas origens, portanto, a AD deriva da incorporação de métodos lingüísticos americanos aos estudos lexicais sociopolíticos na França que dá ensejo ao desenvolvimento de uma análise de natureza sociolingüística.

Antes de dispensar atenção ao "discurso comum e de todas as heterogeneidades" (MAZIÈRE, 2007, p.30), a $\mathrm{AD}$ privilegia os textos políticos escritos, mantendo uma relação intrínseca que acaba estabelecendo uma nova 
compreensão do político e, ao deslocar o lingüístico para assumir um caráter histórico, constrói para si "um lugar particular entre a disciplina lingüística e as ciências das formações sociais" (ORLANDI, 1990, p.25). Em uma interlocução com Courtine (1986), retoma Orlandi (1990, p.31) a história da $\mathrm{AD}$ como um movimento marcado por diferenças e rupturas com "políticas de esquerdas" nos anos 1960 e 1970, na "relação direta dos intelectuais com a política", "entre a prática política e o trabalho teórico". Nesse ínterim, acontece um distanciamento, caracterizado pelo silêncio, a indiferença e o individualismo dos intelectuais que levam ao refluxo e ao próprio vazio político.

Esse distanciamento implica a renovação do positivismo, transformando-se a $\mathrm{AD}$ em "uma prática dividida entre uma função crítica e uma função instrumental". (ORLANDI, 1990, p.31) Em sua função crítica, interroga a própria existência das disciplinas, desterritorializando-as. Mas, ao tempo em que o faz, constrói seus procedimentos, delimita seu objeto e tende, ela mesma, a se territorializar. Nesse processo de territorialização e desterritorialização, a $\mathrm{AD}$ percorre vários continentes. Tendo nascido na Europa, migra para a Grã-Bretanha e os Estados Unidos e se reterritorializa em muitos países da América Latina, inclusive, no Brasil.

Segundo Orlandi (2003, p.1), poderíamos até falar em uma Análise de Discurso francesa, inglesa, americana, brasileira etc., à medida que consideramos a $\mathrm{AD}$ como sendo desenvolvida nesses diversos contextos, "com suas diferentes tradições de estudos e pesquisas sobre o discurso." Na França, especificamente, onde Michel Pêcheux ocupou um lugar privilegiado nos trabalhos de produção do discurso, a AD é concebida como um dispositivo que coloca numa relação complexa o campo da língua 
e o campo da sociedade. Desterritorializando-se, a $\mathrm{AD}$ deixa de se concentrar exclusivamente sobre o discurso político para dirigir sua atenção, também, ao discursivo no campo jornalístico, pedagógico e tantos outros. O redimensionamento do seu território aponta na direção de uma nova concepção discursiva e procedimentos analíticos específicos.

Neste estudo, ao tentarmo-nos (re)aproximar do político, talvez nosso principal desafio seja efetuar uma análise crítica, evitando recorrer a um modelo instrumental. Notadamente porque nos defrontamos com o princípio de que, em $\mathrm{AD}$, tanto o discurso como o sujeito do discurso não constituem "los objetos dados a priori, sino los objetos a construir" (COURTINE, 1981). O fenômeno de investigação, portanto, não pré-existe ao corpus, mas em geral é justamente este que define o primeiro.

Recorremos à $\mathrm{AD}$, contudo, em busca de um aporte teórico-metodológico que pudesse nos ajudar a dimensionar o potencial da manifestação do discurso da industrialização do ensino na política nacional de educação a distância. Adotamos aqui, em particular, a Análise de Discurso de orientação francesa por ser concebida, logo em sua origem, como abordagem capaz de relacionar de forma complexa "o campo da língua (suscetível de ser estudada pela lingüística em sua forma plena) e o campo da sociedade apreendida pela história (nos termos das relações de força e de dominação ideológica)." (GADET, 1990, p.8)

Conforme reconhece Mazière (2007), sobretudo nas últimas três décadas, a $\mathrm{AD}$ encontra na América Latina, e no Brasil de modo especial, lastro para a continuidade de suas referências teóricas, através de estudos e pesquisas que reafirmam sua importância, a despeito de seu 
declínio na própria França, de suas variações e, às vezes até, do emprego "abusivo" do termo escola para nomear sua região de origem. De fato, esclarece Gregolin (2006), são fortes as filiações da $\mathrm{AD}$ brasileira com a mesma base conceitual francesa, mantendo uma tendência a se consolidar como campo fértil e trilhar uma fase avançada no Brasil. Dificulta isso a defasagem em relação à trajetória da AD na França que acabou legando problemas caros aos estudos brasileiros.

Mesmo considerando tais problemas, a hipótese de Gregolin (2006, p.24) é que os estudos recentes desenvolvidos no Brasil estariam "muito próximos" das idéias da AD francesa nos inícios dos anos 1980, quando entra na sua terceira fase. Marcada, principalmente, pelas preocupações de Pêcheux que desloca sua ênfase da formação discursiva para a idéia de "memória discursiva", "interdiscursividade", enfim, "heterogeneidade do discurso". $\mathrm{Na}$ contramão da $\mathrm{AD}$ francesa das últimas décadas, concentrada essencialmente nos fenômenos de natureza lingüística, retórica, pragmática ou interativo-conversacional, observamos no Brasil uma tendência a preservar a dimensão histórica ou político-epistemológica dos discursos (PIOVEZANI FILHO, 2006, p.246).

Seguimos neste estudo a tendência da AD desenvolvida no Brasil, com a pretensão de submeter o discurso em torno da política nacional de educação a distância as suas condições de produção não apenas discursivas, como também extra-discursivas. Engendradas, portanto, nas práticas sociais e discursivas que mobilizam, histórica e continuamente, formações sociais e ideológicas, com as quais a formação discursiva (FD) estabelece relações de interdependência. Daí a necessidade de recorrermos, por um lado, às contribuições de autores de orientação 
marxista, a destacar Bakthin e Pêcheux que nos ajudam a não perder de vista a influência das formações sociais sobre o discurso; e, por outro, às contribuições de um autor como Foucault, cuja noção de formação discursiva e da autonomia do discurso influencia substancialmente as idéias de Pêcheux e da AD francesa.

Além disso, mobilizaremos algumas das contribuições de Patrick Charaudeau para tratarmos, especificamente, do discurso político. Embora Charaudeau se acoste numa linha de pensamento que se orienta pelo viés de uma Teoria Semiolinguística, o autor nos legou recentemente dois estudos que não poderiam deixar de figurar entre nossas referências - "Discurso político" (CHARAUDEAU, 2006) e "Dicionário de análise do discurso", este último em co-autoria com Dominique Maingueneau, um dos principais nomes da AD francesa (CHARAUDEAU; MAINGUENEAU, 2006). Acrescemos a isso o reconhecimento das metodologias contemporâneas em apontar a possibilidade de o pesquisador assumir a inscrição de múltiplos métodos na análise do fenômeno.

\section{MAPA EPISTEMOLÓGICO DA AD}

A Análise de Discurso ${ }^{7}$ inscreve-se numa conjuntura dominada pela invenção do estruturalismo. Segundo Dosse (2007, p.11), o estruturalismo deve ser compreendido como "um movimento de pensamento, uma nova forma de relação com o mundo, muito mais amplo do

7 “O sintagma 'análise do discurso' rapidamente se transformou em 'análise de discurso', permitindo a análise 'dos' discursos, percebidos, por causa do plural, como tipos de discurso." (MAZIÈRE, 2007, p.25) 
que um simples método específico para um determinado campo de pesquisa", que obteve a adesão de grande parte da "intelligentsia", espalhando seus efeitos em inúmeros campos de aplicação das ciências humanas.

O estruturalismo germina no solo francês nos anos 1950, com a pretensão de se constituir "um único e vasto programa de análise" (Michel Serres), colocando-se como "a consciência despertada e inquieta do saber moderno" (Michel Foucault), "a aventura do olhar" (Jacques Derrida) e "a passagem da consciência simbólica para a consciência paradigmática" (Roland Barthes). Sua fonte de inspiração inicial é a lingüística, na versão de Roman Jakobson, que postula que o objetivo das ciências humanas é estudar os sistemas formais. Nessa compreensão, "um signo não tira sua significação de sua relação com o objeto que ele representa, mas de sua oposição com outros signos. Uma língua seria um sistema fechado de significações" (DOSSE, 2007, p.12).

Ao se reterritorializar para outras disciplinas, esse programa colocará em primeiro lugar "o estudo das formas e das relações, excluindo o das substâncias e das qualidades: oposições binárias em Claude Lévi-Strauss, quadro semiótico em Algirdes Julien Greimas, jogos de língua em Jacques Lacan". Idéia também fundamental, de procedência saussuriana, colocará a língua como um sistema preexistente ao uso que dela fazemos e a fala que produzimos, ao utilizar essa língua como representando, exclusivamente, "relações particulares e históricas". Ferdinand de Saussure discorrerá que "a língua é um fenômeno social cujas regras se constituem em plena revelia do sujeito que delas faz uso" (DOSSE, 2007, p.12). No fundo, a lente dosseniana considera o estruturalismo como filosofia para a qual convergem três ciências que atribuem ao 
inconsciente o lugar da verdade: a lingüística, a antropologia e a psicanálise.

Com efeito, marca o surgimento da Análise de Discurso o estabelecimento de uma ruptura com duas posturas teóricas dentro do domínio da linguagem - o estruturalismo (Saussure) e a gramática gerativa - e a sua constituição sob a referência da epistemologia althusseriana. Transformando a lingüística em ciência-piloto, o estruturalismo tentou definir seus métodos a partir da linguagem, estendendo pressupostos linguísticos a quase todas as áreas das ciências humanas e sociais, sem passar por reformulações profundas (HENRY, 1990, p.27). Razão pela qual as referências teóricas que dão origem à AD são encontradas no estruturalismo filosófico dos anos 1960, sobretudo, na sua leitura dos discursos ideológicos, o que vai se refletir, em particular, na rejeição por parte da $\mathrm{AD}$ de "qualquer metalíngua universal supostamente inscrita no inatismo do espírito humano, e toda suposição de um sujeito intencional como origem enunciadora de seu discurso." (PÊCHEUX, 1990a, p.311)

Em sua constituição como campo teórico, que se baseia na reflexão crítica com a finalidade de desvelar os determinantes ideológicos dos fatos ou eventos, a AD acaba articulando três regiões do conhecimento, traçando uma epistemologia que se movimenta no território da formação social, da ideologia, da língua e do discurso, tendo como pressupostos: 1) o materialismo histórico, como teoria das formações sociais e suas transformações; 2) a lingüística, como teoria dos mecanismos sintáticos e dos processos de enunciação; e 3) a teoria do discurso, como teoria da determinação histórica dos processos semânticos (PÊCHÊUX; FUCHS, 1990, p.163-164). Em que a semântica discursiva, como análise dos processos característicos 
de uma FD, deve dar conta da articulação entre o processo de produção de um discurso e as condições em que ele é produzido.

No que diz respeito ao materialismo histórico, a preocupação central de Pêcheux em vincular o discurso à prática política motiva uma opção clara em relação à concepção do sujeito althusseriano que se coloca entre o "sujeito da linguagem" e o "sujeito da ideologia" (HENRY, 1990, p.34). Como explicam Pêcheux e Fuchs (1990, p.165), a região que mais interessa a $\mathrm{AD}$ "é a da superestrutra ideológica em sua ligação com o modo de produção que domina a formação social considerada." Não se reduzindo apenas à expressão da base econômica, a ideologia constitui uma materialidade específica, cujo funcionamento é determinado pela esfera da economia, representando uma das condições da reprodução das relações de produção aí envolvidas. Marca esse funcionamento o processo de interpelação ou de assujeitamento, a partir do qual cada indivíduo - e, por extensão, cada classe ou fração de classe - ocupa um lugar específico no modo de produção.

A reprodução contínua dessas relações de classe dá-se, sobretudo, no contexto dos aparelhos ideológicos de Estado (AIE), onde as posições de sujeito vão constituir formações ideológicas que estabelecem entre si processos de dominação, aliança ou antagonismo. Refletindo essa interrelação numa esfera particular, as formações ideológicas encerram como um dos componentes importantes de sua materialidade as formações discursivas que determinam o funcionamento do discurso numa determinada conjuntura de um AIE e da relação de classes. Decorre daí que o sentido de um discurso só pode ser entendido como pertencente a uma dada FD, determinado isto por um processo que deve estabelecer as relações de paráfrases entre 
seqüências discursivas que, por sua vez, vão constituir a matriz do sentido inerente a essa formação. Produzindo o efeito de assujeitamento no discurso, é o fato justamente de toda seqüência necessitar pertencer a uma FD para adquirir sentido "que se acha recalcado para o (ou pelo?) sujeito e recoberto para este último, pela ilusão de estar na 'fonte do sentido', sob a forma da retomada pelo sujeito de um sentido universal preexistente" (PECCHEUX; FUCHS, 1990, p.169). Não é sem razão que, desde o início, a AD vai se afastar da idéia de análise semântica, pura e simplesmente, de um texto individual.

No que se refere à lingüística, outra região do conhecimento articulada pela $\mathrm{AD}$, sua importância se deve ao fato de constituir uma primeira fase da análise "absolutamente indispensável (não poderia haver aí análise sem uma teoria e uma prática linguísticas), mas insuficiente como tal, na medida em que ela existe com vistas a uma segunda fase" (PÊCHEUX; FUCHS, 1990, p.169). Donde decorre que o reconhecimento da Análise de Discurso como objeto comum de interesse acontece, ao mesmo tempo, em que se buscam métodos de análise lingüística, com uma preocupação de inspiração marxista em relacionar língua e classe social: " para trabalhar com a categoria de discurso, é necessário ser lingüista e deixar de sê-lo ao mesmo tempo." (COURTINE, 1999, p.18)

Numa época marcada por pouco interesse pela obra de Saussurre, Pêcheux revela-se um leitor atento daquele que institui o traço fundamental da lingüística moderna, ao conceber a língua como sistema (GADET et al, 1990, p.42). Provocando um deslocamento conceitual, Saussurre concebe a língua como objeto científico homogêneo, inscrito na região do semiológico e que se estabelece teoricamente sobre duas exclusões importantes: exclui a fala como 
sendo inacessível à lingüística; e exclui as instituições "não-semiológicas" (instituições políticas, jurídicas etc.) da região de interesse dessa ciência (PÊCHEUX, 1990b, p.71).

Apesar de pensar a língua em seu estatuto interno, Saussure reconhece que "é o ponto de vista que cria o objeto", abrindo caminho para se conceber a linguagem a partir de outras perspectivas que não exclusivamente lingüísticas. “O ponto de vista discursivo será um deles, o qual irá recuperar a noção de exterioridade, trazendo-a para dentro da língua, como parte integrante e constitutiva." (FERREIRA, 1999, p.61) Apoiando-se na gramática gerativa de Chomsky, principalmente na oposição estrutura de superfície-estrutura profunda, Pêcheux propõe então a relação entre estruturas discursivas de superfície e aquela que as determina, isto é, a "estrutura invisível".

Dos "Essais de linguistique générale" de Jakobson, Pêcheux (1990b, p.100) extrai proposições importantes para fazer avançar a linguística, enquanto se apóia em Benveniste para elevar a frase à condição de "enunciado", transformado em unidade do discurso, algo que não se reduz à ordem da gramática. No entanto, explica Gadet et al (1990, p.44), é Harris em particular que vai inspirar não só alguns procedimentos de análise, bem como todo o método de Análise Automática do Discurso (AAD), proposto por Pêcheux em 1969, em boa parte, como alternativa crítica à Análise de Conteúdo (NOTAS, 1990, p.153). Nesse sentido, vai perseguir a AD uma luta contra a visão idealista da língua, como percepção ou mesmo origem do mundo, sem reduzi-la à base de um léxico nem de sistemas fonológicos, morfológicos ou sintáticos. A AD concebe a língua como constituindo o lugar material onde se realizam os efeitos de sentido produzidos pelos processos 
discursivos, materialidade esta que enfatiza a idéia de funcionamento de Saussurre, em lugar da idéia de função (PÊCHEUX; FUCHS, 1990, p.179).

Relativamente à teoria do discurso, a terceira região do conhecimento que influencia a $\mathrm{AD}$, devemos ressaltar que Pêcheux acaba criticando sua própria pretensão em tentar formular uma teoria discursiva (MAZIĖRE, 2007, p.11). De todo modo, preocupa o autor questionar os esquemas propostos pelas teorias do comportamento (estímulo-resposta) e da informação (emissor-mensagem-receptor), concebendo o discurso como um "efeito de sentidos" entre interlocutores e não simplesmente como transmissão de informação de um sujeito a outro. Isso implica considerar que um discurso é sempre evocado, a partir de condições de produção determinadas ou representadas na estrutura de uma formação social, além de ser remetido às relações em que é produzido, uma vez que todo discurso remete a um outro: "o objeto de uma sociologia do discurso seria, pois, o de verificar a ligação entre as relações de força (exteriores à situação do discurso) e as relações de sentido que se manifestam nessa situação" (PÊCHEUX, 1990b, p.87).

Nessa perspectiva, a AD trava uma luta contra a tendência das teorias da enunciação, representadas por Benveniste, em reproduzir a ilusão de um sujeito enunciador, portador de intenções, escolhas e decisões. Herdeiras de uma "lingüística da fala", ao conceber o sujeito como origem e operador de seu discurso, essas concepções asseguram a passagem da língua à ordem do discurso, impedindo "que se pense a especificidade do discurso e a questão do assujeitamento, rebaixando-os a uma problemática instrumental da língua em uso." (COURTINE, 1999, p.17). Contrariamente a isso, os processos de enunciação compreendem determinações sucessivas que colocam fronteiras entre o que é selecionado ou dito e o que 
é rejeitado ou não dito pelo sujeito. $\mathrm{O}$ exame das marcas ligadas à enunciação passa a ser essencial à fase de análise lingüística da $\mathrm{AD}$, sugerindo mudanças nas concepções relativas à língua, mormente no que respeita ao léxico e à sintaxe. Na verdade, não é da língua em si ou da materialidade da língua que se pretende tratar, porém do próprio domínio do discurso.

O mapa epistemológico da $\mathrm{AD}$, enfim, é atravessado e articulado por uma teoria da subjetividade de cunho psicanalítico (PÊCHEUX, FUCHS, 1990, p.164) que precede a região do materialismo histórico. Resquício de um distanciamento entre este e a psicanálise, temos a proposição de uma teoria não-subjetiva do uso da linguagem, cuja ênfase reside no fato de que, embora fundamental (não pode haver discurso sem sujeito), a noção de sujeito é descentrada e integrada ao funcionamento dos enunciados, uma vez que o sujeito é constituído socialmente. Não são, portanto, as intenções individuais, mas as convenções articuladas em formações ideológicas que vão constituir o discurso (ORLANDI, 1988, p.10).

Em consequência desse descentramento, a AD francesa vai se apresentar em três momentos, ao longo de sua trajetória até os anos 1980. Caracteriza o primeiro momento, reconhece o próprio Pêcheux (1990a, p.311), um processo de produção do discurso, concebido como uma máquina discursiva "fechada sobre si mesma, de tal modo que um sujeito-estrutura determina os sujeitos como produtores de seus discursos: os sujeitos acreditam que 'utilizam' seus discursos quando na verdade são seus 'servos' assujeitados, seus 'suportes'." Essa noção de maquinaria discursiva de inspiração estrutural é colocada em questão no segundo momento da $\mathrm{AD}$, a partir do instante em que esta insiste na alteridade da identidade discursiva do sujeito. 
A tentativa de instaurar uma nova fase de análise lingüístico-discursiva conduz a $\mathrm{AD}$ a seu terceiro momento, caracterizado por uma maior atenção à heterogeneidade enunciativa e, em particular, ao discurso-outro, concebido sob duas perspectivas: um discurso tomado de empréstimo a outro sujeito; e um interdiscurso que se encontra acima do controle do sujeito enunciador, seja para estruturar estrategicamente seja para desestabilizar o discurso (PÊCHEUX, 1990a, p.317). Além da revisão de conceitos fundamentais, caracteriza essa fase a busca de novos objetos, corpus, métodos e procedimentos de análise que objetivam traduzir a heterogeneidade do sujeito e do discurso, notadamente, em meio a um cenário em que o marxismo e o socialismo são revistos, emerge o processo de globalização da economia e se intensifica a expansão das tecnologias de informação e comunicação (GREGOLIN, 2006, p.20).

Esse amadurecimento da AD implica como um de seus principais resultados a ampliação da compreensão acerca de seu objeto. O discurso passa a ser concebido, segundo Pêcheux (1990c), tanto como estrutura quanto como acontecimento. Estrutura, porque emerge como organização dos dizeres; acontecimento, porque pode essa mesma estrutura ser reorganizada ou reestruturada por força do enunciado, um acontecimento discursivo por natureza. Propondo um novo aporte teórico para a ideologia, o método de Pêcheux se baseia na compreensão das formas materiais da linguagem. "A materialidade específica da ideologia é o discurso e a materialidade específica deste é a língua. O discurso é assim o observatório da relação língua/ideologia." (ORLANDI, 2005)

Sendo assim, acentua Orlandi (2002), a língua assume a condição de possibilidade da emergência do discurso. Diferentemente das noções mecanicistas de informação 
e de mensagem, o discurso é "efeito de sentidos" entre sujeitos que estabelecem uma relação de (contra)argumentação, subjetivação e construção da realidade. Se quisermos determinar a regularidade e o funcionamento do discurso, não devemos opor o produto ao processo discursivo, o sistema à realização do acontecimento ou o social ao histórico. Mais precisamente, Maingueneau (2002) entende o discurso como uma organização que transcende a frase, sendo ele orientado, interativo, contextualizado, assumido por um sujeito, regido por normas e situado no bojo de um interdiscurso. Além disso, não se resume o discurso a uma representação acerca do mundo, mas constitui uma ação sobre este e sobre o outro capaz de relacionar a atividade verbal a atividades não-discursivas.

\section{OBJETO TEÓRICO E OBJETO EMPÍRICO: uma questão de método}

As múltiplas perspectivas de análise utilizadas para observar um fenômeno produzem, segundo Orlandi (1993a, p.15), diferentes objetos de conhecimento, com características próprias e distintas "entre o objeto empírico e o objeto científico que é construído." Diferentemente da lingüística tradicional, a Análise de Discurso não trabalha simplesmente o produto, mas os processos de constituição do fenômeno lingüístico que representam seu recorte teórico fundamental. Para os objetivos da AD, torna-se imperioso que a linguagem seja demarcada pelo seu caráter social, representando o discurso - ainda que sua materialidade, em princípio, seja lingüística - um objeto sócio-histórico, onde o "lingüístico intervém como pressuposto." (PÊCHEUX; FUCHS, 1990, p.188) 
$\mathrm{O}$ mérito da $\mathrm{AD}$, por isso mesmo, repousa sobre o fato de se constituir no lugar em que a linguagem deve se reportar à exterioridade, sobretudo, no sentido de que seu processo significativo seja devidamente determinado. $\mathrm{Na} A D$, não se descreve a função, mas o funcionamento que permite sistematizar, reconhecer regularidades, compreender o discurso como fazendo parte do histórico, do social (ORLANDI, 1996a, p.23). Neste sentido, a AD redefine o lugar do sujeito e a situação de enunciação. Além de conceber esta em sua ordem própria, ao invés de pensar o sujeito como tendo o controle, ou mesmo, identificando-se com o sistema, a AD leva em conta a relação contraditória que o sujeito estabelece com essa estrutura (ORLANDI, 1996b, p.26).

A AD entende a linguagem como trabalho, transformação, produção e interação que se define como uma relação necessária entre homem, realidade natural e social, pois nenhuma linguagem pode se separar da sociedade que a produz. Quando transcende a função referencial da palavra, a AD concebe esta como um "ato social com todas as suas implicações: conflitos, reconhecimentos, relações de poder, constituição de identidades etc." (ORLANDI, 1993a, p.17) Com isso, elimina-se o percurso apenas pelo psíquico ou social, atravessando também o domínio da ideologia. Dessa forma, os interlocutores, a situação, o contexto sócio-histórico, ideológico, ou seja, as condições de produção constituem o sentido da sequiência verbal produzida.

Todo sujeito ocupa um lugar na sociedade e isso faz parte das relações de força no discurso, do que decorre que o princípio fundamental da $\mathrm{AD}$ é considerar que a relação entre a linguagem e a exterioridade é constitutiva e o processo de significação, por natureza, é histórico. Nessas 
condições, o sujeito não se apropria da linguagem individualmente, porque essa ação é social, o que revela o modo como o sujeito o fez, como a ideologia o interpelou. A preocupação da $\mathrm{AD}$ não é realizar isoladamente a análise lingüística do texto nem sociológica ou psicológica do seu contexto, mas sobretudo relacionar a sua enunciação a um lugar social específico e determinado (MAINGUENEAU, 1997, p.13-14).

Não há problemas em reconhecermos que os discursos são feitos de signos, desde que estes sejam concebidos como designando muito mais do que apenas as coisas. Mesmo compreendido como um grupo de enunciados (compostos de signos) que se apóiam numa mesma formação discursiva, para os quais é possível definir uma regularidade ou "o conjunto das condições nas quais se exerce a função enunciativa que assegura e define sua existência" (FOUCAULT, 2002, p.165), o discurso pertence, acima de tudo, ao campo da ideologia. Significa que as formações ideológicas comportam, entre seus elementos, uma ou mais formações discursivas que determinam o que deve e pode ser dito numa determinada conjuntura, "isto é, numa certa relação de lugares no interior de um aparelho ideológico, e inscrita numa relação de classes." (PÊCHEUX; FUCHS, 1990, p.166-167)

Conforme Maingueneau (1997, p.50), na acepção de Foucault a FD diz respeito a um conjunto de enunciados que seguem o mesmo sistema de regras, transcendendo unidades tradicionais como ciência e ideologia; enquanto para Pêcheux, designa o fato de que toda e qualquer formação social encerra posições político-ideológicas não originadas nos indivíduos, mas em formações que mantêm relações complementares ou antagônicas. Segundo o próprio Pêcheux (1988, p.254), o emprego do materialismo 
histórico não se reduz à simples referência às condições de produção sócio-históricas do discurso. Precisamos explicitar, ainda, o conjunto complexo, desigual e contraditório das formações discursivas em jogo numa situação dada, sob a dominação do conjunto das formações ideológicas, tal como a luta ideológica das classes determina.

Uma FD, em princípio, estrutura-se e se impõe de forma hierárquica a todo e qualquer sujeito, através de "enunciados retores" que demarcam o campo dos objetos possíveis e os limites entre o enunciável e o não enunciável (LECOURT, 1971, p.57). Contudo, ela não se estabelece unicamente nem se configura de forma homogênea. Seguindo a noção de Foucault, Pêcheux (1990a, p.314) esclarece que uma dada formação é normalmente invadida por elementos de outras formações discursivas "que se repetem nela, fornecendo-lhe suas evidências discursivas fundamentais (por exemplo sob a forma de 'preconstruídos' e de 'discursos transversos')."

Ao invés de constituir um bloco compacto que se contraporia a outros discursos, a FD é perpassada por uma interdiscursividade que a torna heterogênea por excelência, até porque carrega uma memória discursiva cujas formulações repercutem, recusam e transformam outras tantas formulações (MAINGUENEAU, 1993, p.115). Trata essa memória ou interdiscurso do conjunto de processos discursivos que ajudam a delimitar a atuação das diferentes formações discursivas sobre um discurso. A FD acaba se constituindo, em conseqüência, na relação que estabelece com essa memória do dizer, manifestando no interior deste as formações ideológicas.

Constitui o interdiscurso, por isso mesmo, o espaço ideológico-discursivo através do qual as formações discursivas estabelecem relações de dominação, subordinação e 
contradição. Mediante o interdiscurso, uma FD absorve elementos pré-construídos em outras formações, os quais são correlacionados aos seus "por efeitos-transversos que os incorporam, na evidência de um novo sentido em que eles são 'acolhidos' e fundados" (PÊCHEUX, 1988, p.278). Tanto as anterioridades como as heterogeneidades do interdiscurso não constituem exatamente o contexto, porém encontram-se inscritas "no próprio interior do intradiscurso" (MAZIÈRE, 2007, p.62). Como o interdiscurso encontra-se simulado no intradiscurso, só se tem acesso as suas condições de produção, historicidade ou circunstâncias de enunciação. A constituição do sentido, no entanto, se dá na relação com o interdiscurso, uma trama de sentidos cuja instância de formulação (o intradiscurso) passa pela materialidade do discurso, pela ideologia.

Na realidade, não há discurso que não estabeleça relação com outros, formando uma intricada discursividade, a ponto de um único texto refletir a presença de várias formações que, contraditoriamente, nele se organizam, tendo em vista uma formação dominante (ORLANDI, 2002, p.70). Desse modo, considerando que os indivíduos são interpelados em sujeitos-falantes ou sujeitos de seu discurso por formações discursivas determinadas que, por sua vez, representam na linguagem as respectivas formações ideológicas, concebemos a FD como "aquilo que, numa formação ideológica dada, isto é, a partir de uma posição dada numa conjuntura dada, determinada pelo estado da luta de classes, determina o que pode e deve ser dito" (PÊCHEUX, 1988, p.160-161).

Os objetos que interessam precipuamente à $\mathrm{AD}$ correspondem, por conseguinte, a formações discursivas (MAINGUENEAU, 1993, p.14), donde decorre que as palavras não existem nem guardam um sentido que lhes 
sejam próprios ou intrínsecos a sua possível literalidade. Na realidade, elas adquirem sentido em referência às posições e formações ideológicas nas quais acabam sendo produzidas ou reproduzidas. Mais precisamente, seu sentido se constitui em cada FD que representa o lugar ou matriz dessa constituição, estabelecida através das relações que tais elementos mantêm com outros da mesma formação, o que explica o fato de que, ao passar de uma FD a outra, as palavras acabam mudando seu sentido.

\section{A construção do corpus discursivo}

A relação entre o objeto teórico e o de análise refere a relação estabelecida entre o discurso e o texto. "O objeto teórico é o discurso e o objeto empírico (analítico) é o texto" (ORLANDI, 1996a, p.21). Entendemos o corpus discursivo, por essa razão, como um conjunto de textos estruturados na forma de superfícies lingüísticas que se encontram dominados por condições de produção consideradas estáveis e homogêneas: "um conjunto de imagens textuais ligadas a um 'texto' virtual (isto é, ao processo discursivo que domina e engendra as diferentes seqüências discursivas pertencentes ao corpus)." (PÊCHEUX; FUCHS, 1990, p.239)

Se tais condições devem se apresentar estáveis, o mesmo não ocorre ao próprio corpus que não se trata de um aglomerado estanque de textos, mas um conjunto "sem fronteira", no qual a exterioridade do discurso - o interdiscurso - acaba emergindo no intradiscurso (MAZIÈRE, 2007, p.61). Decorrendo de condições sócio-históricas determinantes à análise lingüística, a constituição do corpus objetiva delimitar e construir os dados e uma teoria relativamente ao exterior do discurso, contribuindo 
para encetar uma perspectiva heurística, um ponto de vista sobre os dados discursivos (CHARAUDEAU; MAINGUENEAU, 2006, p.139).

Considerando que a EAD não pode ser tratada como ciência nem teoria e que a análise das práticas discursivas encontra seu ponto de equilíbrio no saber, em especial, na formação e transformação de um saber, contido não apenas no conhecimento científico como "também em ficções, reflexões, narrativas, regulamentos institucionais, decisões políticas" (FOUCAULT, 2002, p.208), nosso corpus discursivo faz parte de um vasto arquivo, constituído pelos discursos em torno da política de educação a distância no Brasil. Não se confundindo com a noção genérica de registro e preservação de documentos (SARGENTINI, 2006, p.35), o arquivo é concebido como o conjunto de todos os enunciados efetivamente produzidos que circulam em um dado momento histórico (GREGOLIN, 2006, p.27).

Conforme Revel (2005, p.19), a noção de arquivo formulada por Foucault permite a este autor distinguir-se tanto dos estruturalistas, ao considerar o discurso como acontecimento e não sob o ponto de vista do sistema da língua, como também dos historiadores, ao partir do princípio de que os acontecimentos transcendem o presente. Numa acepção foucaultiana, o arquivo não diz respeito à soma dos textos, dos documentos do passado, dos testemunhos da identidade de uma cultura, nem tampouco às instituições encarregadas do registro e conservação dos discursos. Constitui o arquivo as regras de uma prática que rege a emergência dos enunciados como acontecimentos discursivos singulares que subsistem e se modificam regularmente, referindo o sistema geral de discursividade ou de formação e transformação do discurso. 
O arquivo, também, é aquilo que faz com que as palavras e as coisas ditas se agrupem e reagrupem, transitem entre tradição e esquecimento e se atualizem ou desapareçam como enunciados. A revelação, jamais alcançada, do arquivo de uma época, cultura ou sociedade forma, enfim, "o horizonte geral a que pertencem a descrição das formações discursivas, a análise das positividades, a demarcação do campo enunciativo." (FOUCAULT, 2002, p.151) Atualizando essa discussão à emergência dos "bancos de dados", Pêcheux (1997) por sua vez parte da idéia de arquivo em duas vertentes: como campo dos documentos disponíveis e referentes a uma determinada questão; e como instância de gestão administrativa dos documentos, com fins estatais ou comerciais, objetivando facilitar sua comunicação, transmissão e reprodução .

Como resultado do trabalho dos aparelhos de Estado em gerir a "memória coletiva", o emprego crescente do arquivo pelos cientistas acabou contribuindo para o desenvolvimento da informática e de diferentes métodos de análise textual, incluindo a Análise de Conteúdo.

8 Do modo como são concebidos e organizados, os arquivos que pesquisamos se reportam em geral a essa idéia tradicional e instrumental de "arquivo": do grego arkheia, significa documentos do governo; do latim archívum, lugar onde se guardam os documentos. O "Dicionário brasileiro de terminologia arquivística", edição de 2005, oferece quatro definições para arquivo, em sua acepção mais geral: "1 Conjunto de documentos produzidos e acumulados por uma entidade coletiva, pública ou privada, pessoa ou família, no desempenho de suas atividades, independentemente da natureza do suporte. 2 Instituição ou serviço que tem por finalidade a custódia, o processamento técnico, a conservação e o acesso a documentos. 3 Instalações onde funcionam arquivos. 4 Móvel destinado à guarda de documentos." (DICIONÁRIO, 2005, p.27) 
Do ponto de vista de uma concepção discursiva, adverte Pêcheux (1997, p.63), o que devemos enfatizar é a presença da "materialidade da língua na discursividade do arquivo", reconhecendo inclusive as preocupações de historiadores, lingüistas e outros analistas em focalizar "os interesses históricos, políticos e culturais", mediante as mais diversificadas leituras de arquivo.

Como o arquivo em questão, praticamente, é impossível de ser pesquisado no seu conjunto, nosso estudo buscou examinar, em especial, o discurso em torno da política nacional de EAD pronunciado pelo Governo Federal. O que implica, por um lado, contemplar desde os órgãos componentes do primeiro escalão de governo (presidência da República, Ministério da Educação etc.) até as empresas estatais, fundações, autarquias e universidades federais; e, por outro, excluir toda e qualquer instância que aí não se inclua, desde os governos estadual e municipal até as organizações não governamentais.

Direcionamos nossa pesquisa, portanto, para o âmbito macro da política de EAD que, por um lado, abrange todo um sistema federal de planejamento, organização e fomento e, por outro, exclui de sua responsabilidade imediata a execução das práticas de educação a distância no interior dos Estados, municípios e estabelecimentos de ensino. As funções atribuídas à Secretaria de Educação a Distância (SEED) ilustram bem isso, estando aquele órgão basicamente subdividido em três departamentos: Diretoria de Regulação e Supervisão em EAD, Diretoria de Infra-Estrutura em Tecnologia Educacional e Diretoria de Produção de Conteúdos e Formação em EAD. Organizada como uma estrutura complexa que representa o MEC na área de EAD, cabe à SEED, em especial, "formular, propor, planejar, avaliar e supervisionar políticas e programas de 
educação a distância, visando à universalização e democratização do acesso à informação, ao conhecimento e à educação, em todos os níveis e modalidades de ensino" (BRASIL, 2007c).

Entendemos que não constitui um erro utilizar as expressões discurso oficial, discurso governamental ou discurso político como equivalentes, reflexos ou derivações do discurso pronunciado pelo Governo Federal. Primeiro, porque o discurso oficial constitui em geral uma instância de enunciação com legitimidade institucional, portanto, competente e autorizada para representar e expressar o pensamento "oficial" de uma dada instituição. Segundo, porque o discurso governamental tende a constituir a instância de enunciação legítima, competente e autorizada de governo, diferenciada, por essa razão, da "fala" das organizações não governamentais e da sociedade civil como um todo. Nesse sentido, aproximando-nos do pensamento foucaultiano, Chaui (1981, p.7) ressalta que: "O discurso competente confunde-se, pois, com a linguagem institucionalmente permitida ou autorizada, isto é, com um discurso no qual os interlocutores já foram previamente reconhecidos como tendo o direito de falar e ouvir".

Em terceiro lugar, porque assume o discurso de Estado um sentido político, em princípio, como qualquer outro enunciado que a circunstância de enunciação o autorizar. "Não é, portanto, o discurso que é político, mas a situação de comunicação que assim o torna. Não é o conteúdo do discurso que assim o faz, mas é a situação que o politiza." (CHARAUDEAU, 2006, p.40) Mesmo considerando que os lugares de produção, difusão e circulação do discurso político são os mais diversos possíveis, não se reduzindo aos "responsáveis pela governança", torna-se forçoso 
observar que o discurso oficial ou governamental tende a se revestir no discurso político com maior regularidade, ou mesmo, por excelência.

Seguindo Charaudeau (2006, p.40), isso sugere que o discurso do Governo Federal em torno da política de EAD estaria inscrito em meio ou na transição entre o primeiro e o segundo dos três lugares de fabricação do discurso político, a saber, como sistema de pensamento, como ato de comunicação e como comentário. O discurso político como sistema de pensamento resulta de um processo discursivo que objetiva fundar um modelo importante à construção das opiniões e posicionamentos, portanto, às filiações ideológicas. O discurso político como ato de comunicação dedica-se a construir a imagem dos atores participantes da cena de comunicação e a usar estratégias retóricas de persuasão e sedução.

Levando em conta, por outro lado, a sua extensividade, nosso corpus discursivo remonta, praticamente, o conjunto das iniciativas do Estado brasileiro no campo da educação a distância. O que perfaz um período que compreende desde meados do século XX até os anos 2000, por ocasião do governo Lula. Justifica esse recorte amplo o fato de que o fenômeno a investigar - o discurso em torno da política nacional de EAD - não permite ser pensado de forma reducionista, visto que atravessa toda uma fase em que o país decide apostar em sua industrialização e modernização.

Como nos lembra Mazière (2007, p.35), há quatro décadas, Dubois já chamava atenção que "o corpus é uma escolha de difícil extração, dado que é tomado no 'universal do discurso'. Ele será representativo se for homogêneo no tempo e no espaço ('homogeneidade da situação de comunicação') e tradutor de uma ideologia". Levando em 
conta, ademais, que a $\mathrm{AD}$ em geral "não se ocupa de formações discursivas que estariam investidas em um único gênero" (MAINGUENEAU, 1993, p.37) nem que o discurso "se dá como algo discernido e posto" (ORLANDI, 2002, p.63), nosso corpus constitui-se, essencialmente, dos seguintes tipos de documentos e textos: projetos, planos, relatórios e publicações relativas às políticas, programas e ações do Governo Federal na área de educação a distância.

Considerando a diversidade de pontos de vista sobre a noção de gênero, que ora se apegam às características formais ou composicionais do texto, ora à natureza comunicacional ou ancoragem social do discurso, preferimos empregar o termo "tipo". Mais precisamente, tipo de discurso que reputa "uma definição ampla, que o faz designar não importa qual classe de discurso, qualquer que seja o critério que preside seu estabelecimento" (CHARAUDEAU; MAINGUENEAU, 2006, p.468). A expressão tende representar, com mais proximidade, a heterogeneidade do corpus em estudo, cuja especificidade repousa em configurar um discurso de ordem político-institucional ${ }^{9}$.

Os documentos e textos selecionados, por isso mesmo, cumprem um papel que vai além da forma de estatuto ou de registro escrito de como as diversas iniciativas político-institucionais vão forjando e legitimando um discurso

9 Discurso este inscrito, de forma mais ampla, entre os gêneros secundários do discurso que, segundo Bakhtin (1992, p. 281), "aparecem em circunstâncias de uma comunicação cultural, mais complexa e relativamente mais evoluída, principalmente escrita: artística, científica, sociopolítica. Durante o processo de sua formação, esses gêneros secundários absorvem e transmutam os gêneros primários (simples) de todas as espécies, que se constituíram em circunstâncias de uma comunicação verbal espontânea." 
e um ordenamento oficial de política de educação a distância. Por um lado, dado ao caráter plurissemiótico do texto, não há sentido em diferenciar automaticamente o discurso oral do corpus escrito (CHARAUDEAU; MAINGUENEAU, 2006, p.466), mesmo porque este último não representa meramente uma oralidade empobrecida. "Embora o texto seja escrito, ele é sustentado por uma voz específica: 'a oralidade não é o falado', como lembra H. Meschonnie" (MAINGUENEAU, 1993, p.46). Por outro lado, mesmo a enunciação monológica na forma imobilizada de um texto escrito, significa uma resposta ou continuidade a alguma coisa, representa um elemento da comunicação verbal, "um elo da cadeia dos atos de fala." (BAKHTIN, 1988, p.98)

\section{Universo e condições de produção da pesquisa}

Nosso corpus discursivo resulta de uma pesquisa de campo realizada, basicamente, através de dois tipos de levantamento - o primeiro in loco e, o segundo, online, efetuados junto aos arquivos impressos, digitais e eletrônicos de um conjunto de instituições públicas da esfera federal. A pesquisa in loco que empreendemos foi realizada na cidade de Brasília-DF, em setembro de 2006, envolvendo os arquivos de órgãos vinculados ao Ministério da Educação (a SEED e o Centro de Informação e Biblioteca em Educação-Cibec) e o acervo das bibliotecas e sistemas de informação do Senado, Câmara Federal e Universidade de Brasília (UnB).

Além do MEC e o Congresso Nacional representarem organismos com interferência direta sobre a política nacional de EAD, a escolha da Biblioteca Central (BCE) da UnB deveu-se ao fato daquela universidade constituir 
uma das maiores referências em EAD no país, principalmente, na área de formação continuada de professores. A UnB representa uma das quatro universidades brasileiras a manter Cátedra Unesco de Educação a Distância e, em 2006, foi a instituição que mais ofertou ensino a distância no Brasil, desenvolvendo dezenas de projetos, voltados sobretudo para o serviço público: "a proximidade com grandes estatais e com o núcleo político do país a torna mais sensível às agendas desses setores. Ela é procurada para ações corporativas de grande envergadura" (AS INSTITUIÇÕES, 2007, p.39).

Cabe a SEED, no atual governo Lula, planejar, coordenar e supervisionar em torno de duas dezenas de programas e projetos, distribuídos nas seguintes áreas: audiovisual (DVD Escola, Rádio Escola, TV Escola e Luz, Câmera, educAção); mídia digital (Portal Domínio Público, Webeduc, Proinfo, E-Proinfo, Rived e Seednet); ensino (E-Tec Brasil e UAB); pesquisa (Paped) e; formação e capacitação (Formação pela Escola, Mídias na Educação, Proformação e Salto para o Futuro). A simples discriminação dessas ações nos oferece uma idéia aproximada da importância da SEED, sobretudo, levando em conta que sua atuação ultrapassa mais de uma década. A Secretaria chega ao quarto governo, ao segundo presidente da República e a mais de um ministro de Estado, somando em seus quadros alguns secretários e uma série de coordenadores, chefes de departamento e especialistas que, de uma forma ou de outra, contribuíram para consolidar uma posição de instância discursiva privilegiada sobre a EAD no país.

O volume de documentos e textos sob a rubrica da Secretaria, por isso mesmo, não poderia ser ignorado, mesmo porque o leque de suas atribuições e ações 
ampliou-se consideravelmente com a própria modernização do Estado brasileiro, impondo maiores exigências não só em termos de planejamento e gestão, bem como de supervisão e avaliação dos programas. O que implica a elaboração permanente de diretrizes, projetos e relatórios, além da proposição de documentos legais e institucionais para cada programa criado e implementado. Contudo, o levantamento junto aos arquivos da SEED não correspondeu às nossas expectativas, resultando na coleta de alguns poucos relatórios e publicações recém editadas.

Acontece que, assim como ocorria aos demais órgãos ligados ao Ministério da Educação, boa parte do acervo da SEED estava em vias de digitalização, sob o poder do Cibec. Vinculado ao Instituto Nacional de Estudos e Pesquisas Educacionais Anísio Teixeira (Inep), o Centro é responsável pela disseminação de informações educacionais de natureza terciária, secundária (originárias de instituições educacionais públicas e privadas) e primária, produzidas pelo próprio Inep. Apesar de ter sido fundamental para reconhecermos, mais amplamente, o grande arquivo existente sobre a política de EAD que não se resume à atualidade, não foi possível efetuarmos um levantamento exaustivo, como demandava o Cibec. Por diversas vezes, o sistema de acesso ao seu catálogo online tornou-se indisponível. Além dos vários documentos em processo de digitalização, a reprodução de alguns textos também se mostrou restrita: "cópias só poderão ser providenciadas em conformidade com a Lei de Direitos Autorais vigente." (BRASIL, 2007b)

Essas limitações fizeram acentuar a importância de pesquisarmos outros acervos. De sorte que, paralelamente aos arquivos da SEED e do Cibec, conduzimos uma série de levantamentos nas bibliotecas e sistemas de informação 
da UnB, Câmara dos Deputados e Senado Federal. A nossa consulta ao catálogo da Rede Virtual de Bibliotecas Congresso Nacional (RVBI) foi importante, em particular, para vislumbrarmos a importância política atribuída pelo Poder Legislativo ao fenômeno da EAD. Mas, ao mesmo tempo em que constatávamos in loco a "riqueza" daqueles arquivos, problemas de ordem operacional acabaram limitando o levantamento junto aos mesmos. Um deles foi o horário de funcionamento para o usuário externo que se mostrou insuficiente para as pretensões da pesquisa e o outro derivou do fato de que uma série de documentos não pôde ser consultada, por ser de uso exclusivo dos servidores do Congresso (CÂMARA, 2007).

A nossa recorrência à Biblioteca Central da UnB acabou representando, finalmente, alternativa das mais proveitosas para os fins da pesquisa. $\mathrm{O}$ acesso irrestrito ao acervo da biblioteca nos foi crucial, principalmente, para o livre trânsito a uma série de textos e documentos. Graças à natureza, em certa medida, arqueológica da pesquisa, a própria "desatualização" do acervo da BCE tornou-se uma qualidade. A recuperação de uma série de publicações "antigas" ganhou enorme importância, à medida que assumiam elas, de modo especial, a condição de "fiéis depositárias" de traços discursivos que outros momentos sócio-históricos decidiram-lhes imprimir, evidenciado decisivamente que a regularidade do discurso da industrialização do ensino ultrapassava as fronteiras da política atual de EAD.

Mesmo considerando seu curto período de execução e algumas dificuldades enfrentadas, a pesquisa que realizamos em Brasília resultou na recuperação de um material de extrema relevância, parte em sua forma original e a maior parte na forma de cópia integral ou parcial. Trata-se 
de um conjunto de publicações relacionadas às iniciativas do Estado brasileiro no campo da educação a distância, produzidas, editadas, encomendadas ou patrocinadas pelo Ministério da Educação e outros órgãos ligados ao Governo Federal. O material compreende duas dezenas de documentos e textos que servem de base para constituirmos o nosso corpus discursivo.

Por outro lado, a pesquisa a distância que empreendemos, através de levantamento online, foi realizada ao longo de 2007, basicamente, junto a dois endereços eletrônicos de importância capital para dimensionarmos a política educativa brasileira e, em particular, a política de EAD - o Portal do Ministério da Educação (disponível em http:// portal.mec.gov.br) e o Portal Domínio Público (http://www.dominiopublico.gov.br). Apesar de se apresentar importante consultarmos páginas relacionadas aos links Ministério, Áreas, Programas, Sistemas, Autarquias e Serviços que dão a dimensão da estrutura complexa envolvendo o MEC e explicam representar sua home page uma das mais visitadas na internet brasileira (BRASIL, 2007a), seria impossível pesquisarmos o Portal MEC no seu conjunto.

Considerando que, no seu lançamento em novembro de 2004, o Portal MEC já continha "quase 38 mil páginas, entre conteúdo e arquivo" (BRASIL, 2004a), demos ênfase à página da Secretaria de Educação a Distância (http:// portal.mec.gov.br/seed), órgão diretamente responsável pela política e programas em EAD. A página da SEED nos foi de extrema relevância para levantarmos, consultarmos e recuperarmos informações e arquivos de natureza administrativa, político-institucional e legal. Encontramos ali disponibilizados, grosso modo, três tipos de dados: legislação, regulamentação e referenciais de qualidade 
para a EAD nacional; apresentação, estruturação, projetos e programas desenvolvidos pela Secretaria; e, por último, notícias produzidas pela Assessoria de Imprensa da SEED, publicadas na sua própria home page e através da Seednet, uma revista eletrônica (http://www.seednet. mec.gov.br).

Concentramos a pesquisa, todavia, junto aos links que remetiam aos diversos programas conduzidos pela SEED, uma vez que tendiam a expressar mais direta e explicitamente a orientação da política nacional de educação a distância. Parte deles oferecia poucos dados, resumidos em geral a informações sobre objetivos, organização, funcionamento e alcance. Caso dos programas DVD Escola, que não possuía home page, até porque configura uma extensão da TV Escola; Programa de Apoio à Pesquisa em Educação a Distância (Paped), cujo site encontrava-se desatualizado (http://paped.proinfo.mec.gov.br/); Luz, Câmera, EducAção, abrigado como um link na página da Seednet; e WebEduc, o Portal de Conteúdos Educacionais do MEC (http://webeduc.mec.gov.br/) que não disponibilizava informação própria, mas "material de pesquisa, objetos de aprendizagem e outros conteúdos educacionais de livre acesso", produzidos por instituições, portais nacionais e estrangeiros, além de programas da SEED/ MEC (BRASIL, 2007d).

Um dos programas disponibilizados pelo WebEduc tratava-se da Rede Interativa Virtual de Educação (Rived), em cuja home page (http://www.rived.mec.gov. $\mathrm{br} /$ ) encontramos notícias, artigos e, principalmente, conteúdos pedagógicos digitais na forma de objetos de aprendizagem. Além dos links localizados na própria página da SEED, assim como o Rived, outros programas dispunham de sua própria home page. Incluíam-se aí o FormAção 
pela Escola que mantinha o SIFE, um sistema de informação vinculado ao programa (http://sife.proinfo.mec. gov.br/principal/index.php); o Programa de Formação de Professores em Exercício (Proformação) que, além do seu Sistema de Informações (SipWeb), dispunha de site próprio (http://proformacao.proinfo.mec.gov.br/); e o e-ProInfo que, por natureza, já constituía um Ambiente Colaborativo de Aprendizagem a Distância (http:// www.eproinfo.mec.gov.br/).

O acesso ao programa FormAção pela Escola somente era permitido ao usuário cadastrado no SIFE e, em se tratando do Proformação e e-ProInfo, o visitante podia acessar basicamente os links informacionais a respeito dos dois programas. Utilizando o e-ProInfo e o seu próprio site (http://www.webeduc.mec.gov.br/midiaseducacao/index.php) como ambientes de aprendizagem, o Programa de Formação Continuada em Mídias na Educação disponibilizava uma série de módulos de estudos, uma vez objetivar "ser uma referência para cursos on line" (BRASIL, 2007e), promovendo a formação continuada para o "melhor uso" das mídias, a "avaliação crítica" de sua aplicabilidade e o desenvolvimento das "habilidades e competências necessárias" no campo das tecnologias educacionais (BRASIL, 2007f).

Os programas mais antigos e recentes, até por sua complexidade e posição estratégica em meio à política conduzida pela SEED, representavam todavia aqueles que disponibilizavam acervo digital e eletrônico mais volumoso. Tratavam-se eles de o Salto para o Futuro, TV Escola, Programa Nacional de Informática na Educação (ProInfo), Rádio Escola, Universidade Aberta do Brasil (UAB) e Escola Técnica Aberta do Brasil (e-Tec Brasil). À exceção da TV Escola, cujos dados encontravam-se 
disponíveis na página da SEED, os demais programas mantinham suas home pages, com diversos links, em geral, acessíveis a qualquer usuário.

A TV Escola, canal de televisão do MEC destinado à formação continuada dos educadores, enriquecimento da aprendizagem e melhoria da qualidade do ensino básico, representava o programa que disponibilizava o acervo mais rico. Em meio a informações gerais sobre o programa, dois links se destacavam na página da TV Escola - Biblioteca e Salto para o Futuro. Este último remetia a home page do programa homônimo (http://www.tvebrasil.com.br/salto/), produzido pela TVE Brasil e exibido diariamente pelas TVs educativas e comerciais, objetivando a formação continuada e aperfeiçoamento dos professores de educação básica. Através do link Biblioteca, a SEED tornava acessível um conjunto de documentos e textos, produzidos em torno do programa, incluindo projetos e relatórios anuais de gestão da SEED, como o de 1996 que ressaltava: “A programação plurianual da SEED está sistematizada em documentos preliminares, devendo se constituir em base para a definição de uma Política Nacional de Educação a Distância." (BRASIL, 1996, p.2)

Terceiro programa mais antigo da SEED, depois do Salto para o Futuro e TV Escola, o ProInfo encontrava-se também entre aqueles que disponibilizavam maior número de informações, dados e estatísticas a respeito do seu funcionamento e alcance. Apesar de não constar na página da SEED nenhum dispositivo de acesso, o ProInfo também mantinha sua própria home page (http://www. proinfo.mec.gov.br/), na qual se destacava o link Biblioteca que disponibiliza um acervo de documentos e textos, dentre os quais as publicações da "Coleção Informática para a Mudança na Educação". 
Entre os programas mais antigos conduzidos pela SEED, o Rádio Escola representava aquele que menos envolvia textos e documentos, trazendo o seu site (http://200.130.3.122/) poucas informações sobre o programa, além do acesso a três projetos: Educomunicação pelo Rádio em Escolas do Ensino Médio da Região Centro-Oeste (Educomrádio.centro-oeste), Escola Brasil e Séries Rádio Escola, subdividindo-se este último na Série do Professor, Série do Aluno e Série do Radialista que visavam promover atividades pedagógicas no âmbito da alfabetização.

A principal diferença entre os novos programas Sistema Universidade Aberta do Brasil e Escola Técnica Aberta do Brasil em relação aos mais antigos, particularmente TV Escola e ProInfo, é que nem a UAB (http://uab. capes.gov.br/) nem a e-Tec Brasil (http://www.etecbrasil.mec.gov.br/index.php) faziam constar, em suas home pages, históricos ou relatórios de atividades. A não ser na forma de dados e informações gerais sobre seus objetivos, diretrizes, regulamentação, estrutura e funcionamento, além de seus ambientes de trabalho e de comunicação do sistema, destinados à interação entre especialistas e técnicos que atuam junto aos programas. Os seus ambientes de aprendizagem, tendo como base a plataforma Moodle, são disponibilizados diretamente pelas instituições de ensino participantes.

Já o Portal Domínio Público - segundo endereço eletrônico de fundamental importância à pesquisa online que realizamos - apresentava o mérito de armazenar e tornar acessível, entre outros, todo um acervo importante à política educativa brasileira, às vezes até, não encontrado nem mesmo nas respectivas páginas ou sites dos demais programas. Em parceria com a Organização das 
Nações Unidas para a Educação, a Ciência e a Cultura (Unesco), em 2006, foram digitalizadas para aquele Portal por volta de 300 mil páginas de arquivos do Inep e do Conselho Nacional de Educação (CNE) e, além do acervo da Fundação Joaquim Nabuco, a meta para 2007 era "higienizar, restaurar e digitalizar obras raras armazenadas no Colégio Pedro II (RJ)." (BRASIL, 2006c)

A coleção do Portal Domínio Público que interessou, mais diretamente, a nossa pesquisa referia-se às "Publicações sobre Educação", cujo acervo textual em janeiro de 2008 chegava a mais de 2.700 itens cadastrados. Desse total, quase 1.800 itens ou 2/3 registravam autoria do MEC, incluindo secundariamente as diversas secretarias e demais órgãos a ele vinculados. Mesmo descrita como "autor" de apenas três dezenas de registros (BRASIL, 2008d), a SEED aparecia participando da autoria de várias outras obras, muitas vezes, de sua iniciativa, mas cuja normalização bibliográfica obedecia a NBR 6023, de agosto de 2002, da Associação Brasileira de Normas Técnicas (ABNT), que prevê, nos casos de autor entidade: "Quando a entidade tem uma denominação genérica, seu nome é precedido pelo nome do órgão superior, ou pelo nome da jurisdição geográfica à qual pertence." O tempo disponível não foi suficiente para pesquisarmos toda a coleção, mas consultamos 1.200 itens que equivaliam a quase $45 \%$ do total.

A nossa pesquisa online no geral culminou, portanto, na recuperação de um material de extrema relevância, todo ele na forma de cópia digital integral. Inclui o mesmo um conjunto de publicações relacionadas à política nacional de educação a distância, principalmente, nas últimas duas décadas, produzidas, editadas, encomendadas ou patrocinadas, em sua maioria, pelo MEC e órgãos a ele 
vinculados, a destacar a SEED. O material compreende três dezenas de documentos e publicações que - somados àqueles coletados através da pesquisa in loco - servem de base para extrairmos nosso corpus de análise.

Nosso corpus discursivo, enfim, resulta de uma seleção intencional efetuada junto ao conjunto de cinco dezenas de documentos e textos, coletados através dos levantamentos in loco e online, acima descritos. Desse total, constitui nosso corpus os dez textos constantes do Quadro 1, a seguir apresentado:

\begin{tabular}{|c|l|c|}
\hline Texto & \multicolumn{1}{|c|}{ Título } & Ano \\
\hline T1 & $\begin{array}{l}\text { Universidade Aberta do Brasil: democratização do } \\
\text { acesso à educação superior pela rede pública de } \\
\text { educação a distância }\end{array}$ & 2006 \\
\hline T2 & $\begin{array}{l}\text { Política e resultados 1995-2002: tecnologias na } \\
\text { educação básica }\end{array}$ & 2002 \\
\hline T3 & Dois anos da TV Escola & 1999 \\
\hline T4 & $\begin{array}{l}\text { Educação a distância: integração nacional pela } \\
\text { qualidade do ensino }\end{array}$ & 1992 \\
\hline T5 & $\begin{array}{l}\text { 1985: Mensagem apresentada ao Congresso Nacional } \\
\text { Felo Presidente da República, João Baptista de Oliveira }\end{array}$ & 1987 \\
\hline T6 & Projeto Logos II & 1975 \\
\hline T7 & Relatório da teleducação & 1973 \\
\hline T8 & Projeto Saci: relatório no II: parte A & 1968 \\
\hline T9 & Projeto Saci: parte I & $\begin{array}{l}\text { A educação e o treinamento por correspondência: } \\
\text { histórico e potencialidades }\end{array}$ \\
\hline T1 & & \\
\hline
\end{tabular}

QUADRO 1 - Corpus discursivo

FONTE: Pesquisa de campo, através de levantamento in loco e online 
Os dez textos que constituem nosso corpus discursivo foram selecionados a partir de alguns critérios que consideramos importante ressaltar. O primeiro deles é de ordem temporal e se deveu à preocupação em darmos conta de todo o período histórico que abrange o corpus, compreendendo um total de seis décadas que vão desde os anos 1950 até os anos 2000. À exceção das décadas de 1950 e 1980, em relação a cada qual nossa pesquisa resultou tão somente em um único texto (T10 e T5, respectivamente), todas as demais são representadas por intermédio de dois textos que permitem evidenciar, mais sistematicamente, a regularidade do discurso em análise. O parâmetro que serviu de base para essa escolha foi o fato de termos coletado apenas dois textos (T8 e T9) referentes à década de 1960.

O segundo critério, de caráter linguístico, derivou da intenção em selecionarmos textos que representassem os mais diversos tipos ou gêneros de documento oficial. Nosso corpus acaba reunindo desde o artigo publicado em coletânea (T1 e T3), passando pelo ensaio na forma de livro-texto (T10), até a mensagem presidencial (T5) e um conjunto de documentos de natureza político-administrativa. Destacam-se entre esses os projetos (T4, T6 e T9) e os relatórios (T2, T7 e T8), ora referentes a programas específicos ora relacionados à política de EAD em geral.

O terceiro critério, de natureza discursiva, decorreu da necessidade de contemplarmos as temáticas que poderiam representar, de modo mais significativo, o corpus discursivo. Nesse sentido, especialmente os textos referentes às décadas de 1950, 1970, 1990 e 2000, foram selecionados levando-se em conta o fato de se reportarem, já em seus títulos, a quatro discursos que vão se apresentar de suma importância à política nacional de EAD: as tecnologias 
educacionais (T2, T3 e T7), a formação continuada (T6 e T10), a democratização da educação (T1) e a qualidade do ensino (T4).

Por último, o quarto critério que definiu a constituição do nosso corpus teve como base uma opção de ordem epistemológica. O fato de termos selecionado dez textos para análise deveu-se não apenas a uma questão de organização do material e da quantidade de dados que se ofereciam, mas também porque a relação da $\mathrm{AD}$ com o corpus não é de natureza positivista. Além de não considerar o corpus como um conjunto apenas de dados empíricos objetivos, não interessa à $\mathrm{AD}$ nem sua exaustividade nem sua extensividade enquanto materialidade linguística.

\section{Procedimentos de análise}

A sistemática que adotamos para análise do corpus discursivo baseia-se menos em um procedimento de inteligibilidade ou interpretação e muito mais em um esforço de compreensão de como o objeto simbólico produz sentidos e de como estes transcendem ou estão aquém e além das palavras (ORLANDI, 2002, p.26). Isso não significa que estejamos ignorando que o resultado da Análise de Discurso constitui uma interpretação, cuja tradição vai "da hermenêutica à simples explicação do texto." (MAZIÈRE, 2007, p.25) De todo modo, como ressalta Orlandi (1993a, p.117), a AD não constitui um método de interpretação, mas essencialmente de compreensão: “Compreender, na perspectiva discursiva, não é, pois, atribuir um sentido, mas conhecer os mecanismos pelos quais se põe em jogo um determinado processo de significação."

Com base nesse pressuposto, devemos partir inicialmente do enunciado como unidade de referência, 
concebendo-o não como uma estrutura frasal, proposicional ou um ato de linguagem. Mas como uma função de existência pertencente, de forma exclusiva, aos signos: "se eles 'fazem sentido' ou não, segundo que regra se sucedem ou se justapõem, de que são signos, e que espécie de ato se encontra realizado por sua formulação (oral ou escrita)." (FOUCAULT, 2002, p.98-99) Além de não separar o enunciado de suas condições de produção nem de sua estrutura linguística ou das interações de ordem subjetiva (MAZIÈRE, 2007, p.13), ao considerar o enunciado como unidade central da teoria do discurso, a AD o toma em sua singularidade e repetição, dispersão e regularidade, com o objetivo de compreender os acontecimentos discursivos (emergência de enunciados) que produzem e cristalizam efeitos de sentido na sociedade (GREGOLIN, 2006, p.27).

Outras vezes, devemos partir do próprio texto, reconhecendo que o mesmo não se reduz a um objeto empírico, de natureza meramente linguística, com começo, meio e fim. Tomaremos o texto como "uma unidade complexa de significação", observando a sua incompletude textual (manifestada pelo inesgotamento de sentidos que o discurso transporta) como a "condição de existência da linguagem", o olhar sob as condições de sua produção e a sua constituição no processo de interação, no qual o sentido aloja-se no espaço discursivo engendrado pelos interlocutores. No entanto, precisamos observar que o texto não pode ser confundido com o discurso nem muito menos com a unidade de construção deste último, tratando-se na verdade da unidade de análise: "a unidade de construção do discurso é o enunciado mas ele tem de ser referido ao texto para poder ser apreendido no processo de construção do discurso." (ORLANDI; GUIMARÃES, 1988, p.22) 
Assim procedendo, tentamos evitar incorrer no equívoco de uma análise reducionista que leva em consideração apenas parte do texto, "deixando na sombra" o seu contexto (LECOMTE; LÉON; MARANDIN, 1990, p.293). Distintamente da frase, que se organiza entre signos e proposições, o texto é concebido por Pêcheux (1990b) não como produto, mas como processo discursivo que pressupõe condições concretas de produção, diferentes posições de sujeito e várias formações discursivas em torno de uma dominante. Embora possa ser considerado uma unidade completa para efeito de análise, o texto não representa unidade fechada em si mesma, face as suas intrínsecas relações com outros textos, condições de produção e exterioridade constitutiva. O texto constitui "o vestígio mais importante" da materialidade histórica da linguagem, podendo assumir, do ponto de vista da discursividade, desde a extensão de uma simples letra ou enunciado até a condição de um romance completo. Mesmo representando um "dado" da língua, o texto caracteriza muito mais um "fato" discursivo, um objeto simbólico que "organiza a relação da língua com a história no trabalho significante do sujeito em sua relação com o mundo." (ORLANDI, 2002, p.69)

Os enunciados ou textos selecionados deverão ser concebidos como superfície lingüística, uma seqüência oral ou escrita de dimensão variável que representa o objeto empírico, ou seja, o discurso concreto em seu estado puro. Nesses termos, serão submetidos a um processo de de-superficialização que se caracteriza pela transformação do discurso de objeto empírico em objeto discursivo, em objeto de natureza teórica (PÊCHEUX; FUCHS, 1990, p.180). Nessa acepção, o discurso é compreendido como objeto ou espaço teórico linguístico e histórico que nos permite analisar a relação entre a língua e a ideologia. 
A formação do objeto discursivo deve ser descrita, dessa forma, através da identificação das relações que caracterizam uma prática discursiva, estabelecidas entre instituições, processos econômico-sociais, sistemas de normas etc., que definem o campo da exterioridade do objeto, como também da materialidade lingüística que, por sua vez, diz respeito a quem fala, como fala, em que circunstâncias, entre outros condicionantes. Deveremos entender, então, como o texto é produzido, considerando, por um lado, suas condições de produção em sentido estrito - o contexto imediato - e, por outro, suas condições de produção em sentido amplo - o contexto sócio-histórico e ideológico (ORLANDI, 2002, p.26). Precisamos referir o discurso ao conjunto de discursos possibilitados pelas condições de produção (PÊCHEUX, 1990b), cujos elementos estruturais compreendem, por um lado, o referente, o contexto ou a situação de enunciação na qual irrompe e se processa o discurso, que aliás não trata da realidade física, mas de um objeto imaginário, concebido desde o ponto de vista de cada sujeito; e, por outro, os sujeitos do discurso que, antes de constituírem indivíduos isolados, designam lugares delimitados na estrutura de uma formação social e que se fazem representados ou transformados no processo discursivo.

Nesse sentido, a situação de enunciação e o sujeito envolvido nela dizem respeito a uma posição que é determinada pela relação com outras posições de sujeito, derivadas das diversas formações discursivas que se debatem em meio a uma conjuntura sócio-histórica. Em outras palavras, trata-se de evidenciarmos o esquema enunciativo, determinando os papéis relacionados a sua produção, destacando-se aqueles ocupados pelo locutor e interlocutor, o enunciador responsável pelo discurso e 
o seu destinatário. Entender a dimensão desses elementos, identificando inclusive cada participante ou grupo envolvido, com suas expectativas materiais ou simbólicas concretas e específicas, evita-nos incorrer no equívoco de considerar o sujeito como origem do sujeito, ou melhor, "o sujeito do discurso como origem do sujeito do discurso." (PÊCHEUX, 1988, p.158)

Levando em consideração as diversas modalidades enunciativas (status ou direito de fala, lugares institucionais, posição ocupada), deveremos entender o discurso como o lugar da dispersão e da descontinuidade do sujeito em relação a si próprio, "um espaço de exterioridade em que se desenvolve uma rede de lugares distintos." (FOUCAULT, 2002, p.62) Ao mesmo tempo em que é interpelado por uma formação ideológica e discursiva, o sujeito do discurso é igualmente sobredeterminado pelos dispositivos de comunicação que lhes impõe lugares, papéis e comportamentos definidos (CHARAUDEAU; MAINGUENEAU, 2006, p.115) e por uma memória discursiva, "à medida que uma formulação-origem regressa à atualidade de uma 'conjuntura discursiva' que denominamos de efeito de memória." (COURTINE, 1981)

Definido o objeto e o sujeito discursivo, cabe então reconhecermos que entre um sistema de formação ideológica e um sistema discursivo dá-se o funcionamento do discurso. Mecanismo este que não pertence ao próprio discurso nem à língua, mas resulta da utilização por parte dos sujeitos de elementos lingüísticos, formações ideológicas e discursivas objetivando produzir efeitos de sentidos. Trata-se de atingirmos, em consequência, o processo discursivo, caracterizado pelo fato de que todo discurso se origina de um anterior e, de imediato, aponta na direção de um posterior, significando que representa muito mais 
um "continuum" do que um discurso único, fechado e acabado (ORLANDI, 1993a, p.18).

A nossa atenção, portanto, não deve se limitar à organização do texto, mas àquilo que este organiza em termos de discursividade. O desafio, nesse sentido, será percorrermos o modo como a ordem do discurso materializa-se através da organização do texto, remetendo este a um discurso e vinculando suas regularidades a uma determinada formação discursiva que, finalmente, encontra sentido na respectiva formação ideológica. Segundo Courtine (1981), a formação ideológica possui um caráter específico e compreende posições de classe, o que explica que se pode tratar, a partir de formações ideológicas antagônicas, dos mesmos objetos (como a política de EAD) de forma diferente. A FD, por sua vez, é um componente interligado à formação ideológica, podendo constituir esta várias formações discursivas que se distinguem umas das outras, mantendo relações contraditórias inscritas, necessariamente, em sua própria materialidade lingüística.

Como nosso estudo tem em vista um discurso político por excelência, do mesmo modo que precisamos vincular o funcionamento do discurso a sua exterioridade, torna-se imprescindível compreendermos como o processo discursivo relaciona a FD a uma formação ideológica. Em texto escrito em co-autoria com Catherine Fuchs, Pêcheux (1969 apud MAZIÈRE, 2007, p.51) já atribuía peso fundamental ao estabelecimento dessa relação: "as formações discursivas estão ligadas às superestruturas (no sentido marxista do termo), ao mesmo tempo, como efeitos e como causas. Uma teoria do 'efeito discurso' não pode ignorar esse ponto".

Como o que estará em jogo, enfim, não é mais o texto, mas o próprio discurso em seu modo de funcionamento, 
buscaremos compreender nosso corpus discursivo de acordo com os dispositivos teóricos anteriormente estabelecidos, no caso aqui analisado, à luz das características estruturais da industrialização do ensino. Diferentemente da lingüística, a $\mathrm{AD}$ não trabalha direta nem exclusivamente com as marcas discursivas (formais), mas com propriedades discursivas (materiais) que atribuem sentido ao discurso, referindo a língua à história. $\mathrm{O}$ que importa à $\mathrm{AD}$ é o modo como essas marcas articulam-se no texto ou "se 'encarnam' no discurso. Daí o interesse do analista pela forma-material que lhe permite chegar às propriedades discursivas." (ORLANDI, 2002, p.90)

Sem conseguir dar conta do funcionamento discursivo, as marcas dizem respeito tão somente à organização do enunciado, enquanto as propriedades levam em consideração os vínculos deste com a exterioridade, o contexto sócio-histórico e político-cultural. Apesar de ser indireta a vinculação do texto com os seus condicionantes, não é possível distinguir o discurso sem levar em conta sua historicidade, "pois o estabelecimento da propriedade do discurso é o estabelecimento do funcionamento típico de suas condições de produção." (ORLANDI, 1993a, p.26) Nesses termos, consideramos que as propriedades discursivas da política nacional de educação a distância estariam relacionadas, direta ou indiretamente, às seguintes condições materiais e estruturais da industrialização do ensino: racionalização, divisão de trabalho, mudança de função e especialização, mecanização, linha de montagem, produção de massa, trabalho preparatório, planejamento, organização, métodos de controle científico, formalização, padronização, objetivação, concentração e centralização. 


\section{Dispositivo analítico}

A prática da análise textual precisa levar em conta que um texto comporta uma série de "efeitos possíveis", correspondentes não apenas aos efeitos pretendidos pela instância de enunciação como àqueles produzidos por parte da instância de interpretação (CHARAUDEAU; MAINGUENEAU, 2006, p.180). A compreensão de como um objeto discursivo produz efeitos de sentido acaba, por extensão, dando continuidade a esse processo, colocando em circulação não só uma compreensão, como também uma nova pretensão em matéria de efeitos. "Produzem-se assim novas práticas de leitura." (ORLANDI, 2002, p.27)

Caberá ao analista, apoiado em um referencial teórico-metodológico consistente, problematizar e produzir novas práticas de leitura relativamente ao objeto discursivo, com base em conceitos que lhe são intrínsecos, específicos e, por assim dizer, diferentes daqueles empregados por outros pesquisadores. O que implica numa distinção entre o dispositivo teórico e o analítico que, por sua vez, faz parte e individualiza o teórico, a cada análise efetuada. "Daí dizermos que o dispositivo teórico é o mesmo mas os dispositivos analíticos, não. O que define a forma do dispositivo analítico é a questão posta pelo analista, a natureza do material que analisa e a finalidade da análise." (ORLANDI, 2002, p.27)

Em nossa análise, portanto, o que iremos enfatizar é a relação do objeto empírico (o texto) com o objeto teórico (o discurso). De modo que os textos não serão tratados como "meras ilustrações", pois, na perspectiva da $\mathrm{AD}$, "não há possibilidade de exaustividade extensional/ horizontal, porque todo discurso se estabelece sobre um discurso anterior e aponta para outro (que é o seu futuro)" 
(ORLANDI; GUIMARÃES; TARALLO, 1989, p.32). No próximo capítulo, tentaremos dar conta de como essa relação reflete as condições sócio-históricas de produção de cada texto e do corpus discursivo no seu conjunto. Além disso, buscaremos apontar como essa relação se estabelece sob o impulso do interdiscurso, que permeia todo o corpus, e do intradiscurso, que intervém sobre o âmbito estrito de cada texto.

Aliás, é possível realizarmos vários procedimentos em $\mathrm{AD}$, limitando-nos a um texto e procurando as pistas que o caracterizam, a fim de analisar palavras, expressões ou frases. Para os objetivos delineados neste estudo, pareceu-nos mais adequado entretanto tomar fragmentos de textos diferentes que tratam do mesmo fenômeno. Objetivamos recuperar no corpus pesquisado, numa acepção foucaultiana, "os traços discursivos suscetíveis de permitir a reconstituição do conjunto das regras que, num momento dado, definem ao mesmo tempo os limites e as formas da dizibilidade, da conservação, da memória, da reativação e da apropriação" (REVEL, 2005, p.18).

Nessa perspectiva, mediante escolha intencional, tomamos como unidade significativa de análise do nosso corpus não diretamente cada texto, na sua íntegra, mas a seqüência discursiva de referência (sdr) que melhor representava as propriedades discursivas fundamentais à política nacional de EAD. Seguindo Courtine (1981), partimos do pressuposto de que a produção de uma sdr apresenta-se fortemente associada à difusão e circulação de todo um conjunto de textos, de natureza e procedência diversas, que a precederam e a prepararam, dos quais constitui o ponto culminante, que os sucedem e os respondem, formando, por conseguinte, o domínio de atualidade do acontecimento discursivo que representa. 
Em complemento a esse critério de representatividade, boa parte das seqüências selecionadas foi extraída do tópico correspondente à introdução de cada texto. São exemplares, neste sentido, as sdr 1, 3, 6 e 10 que representam uma espécie de introdução à introdução. As sdr 2, 4 e 8, por sua vez, fazem parte da introdução. Por último, as sdr 5, 7 e 9 encontram-se no entremeio dos respectivos textos. A organização de cada seqüência leva em conta um conjunto significativo de parágrafos, aos quais estamos denominando de segmentos discursivos, formados por diversos tipos de fragmentos (palavras, expressões, frases, enunciados, séries discursivas etc.). Considerando que a $\mathrm{AD}$ não se preocupa diretamente com a forma ou a extensividade do texto, mas com a sua discursividade, os segmentos apresentam dimensão variada, compreendendo desde dois a sete parágrafos, havendo uma ênfase de parte das seqüências em ser composta por três segmentos (sdr 1, 2, 3, 6 e 8).

Cada sdr não só corresponde, assim como visa representar um dos dez textos que constituem nosso corpus discursivo. Elegemos a sdr 1 como seqüência-modelo, pela importância especial que ela encerra, conforme esclarecemos no próximo capítulo. Ela assume, dessa forma, um propósito bem mais amplo que as demais sequiências, contribuindo para vislumbrarmos como as condições de produção ajudam a organizar e transcender a regularidade do discurso da industrialização do ensino. Por um lado, examinamos como a própria sdr 1 organiza-se tanto lingüística como discursivamente, dando ênfase a sua intratextualidade e intradiscursividade. Por outro, tentamos dar conta de como a sdr 1 e o T1 como um todo organizam-se em termos de intertextualidade e interdiscursividade face aos mesmos (seqüência e texto) e a outros 
textos e discursos presentes, seja no seu interior seja em sua exterioridade.

Daí nosso cuidado em decompor e analisar a sdr 1 e o T1 da forma a mais detalhada e abrangente possível. O que implicou, em primeiro lugar, identificarmos a situação de enunciação que envolve o discurso, incluindo o lugar e tempo em que ocorre, além do lugar social e a posição do sujeito falante e destinatário. Em segundo lugar, procuramos evidenciar como esses sujeitos, ou melhor, os sujeitos da história comportam-se entre si, fazendo uso da voz ou sendo induzidos ao silêncio, o que nos levou a identificar, por um lado, um sujeito silenciado e, por outro, um sujeito ao mesmo tempo determinado, competente e autorizado.

Em terceiro lugar, foi-nos extremamente importante desvendar a materialidade do discurso, compreendendo desde o gênero textual e a forma de linguagem até a estratégia e o tipo de discurso prevalecente. Do que resultou apontarmos um discurso nos padrões de um artigo de natureza acadêmico-científica, apresentado de forma didática e com pretensões dialógicas, porém marcadamente autoritário. Em quarto lugar, preocupou-nos examinar a continuidade e a descontinuidade do discurso que, por conseguinte, revelou encontrar-se a sdr 1 intensamente afetada por uma regularidade discursiva. Em quinto lugar, buscamos esclarecer como os enunciados apontam na direção de acontecimentos discursivos, concebidos como subdivididos em três níveis de acontecimentos interdependentes e correspondentes às instâncias da produção, difusão e circulação do discurso.

Por último, conjuntamente com o T1, a sdr 1 é tomada para entendermos como o sistema de enunciabilidade do discurso em torno da política nacional de EAD é organizado para fazer prevalecer a industrialização do ensino 
enquanto formação discursiva dominante. Seguindo esse pressuposto, todas as demais sequências discursivas de referência têm o propósito de evidenciar, fundamentalmente, a incidência das características da industrialização do ensino sobre cada texto, através de fragmentos que lhe são correspondentes, mesmo que reiterados na forma de paráfrases ou famílias parafrásticas ${ }^{10}$. Quando as correlacionamos sob o prisma de sua materialidade e, sobretudo, de sua própria historicidade, tais sequências enfim dão sentido ao nosso corpus discursivo. Material este composto por um conjunto de enunciados, resultante de um discurso produzido em uma situação concreta de enunciação por sujeitos e, no evento dessa enunciação, materializado em textos, entendidos como uma unidade lingüística concreta e de sentido, construída segundo regras e princípios discursivos determinados sócio-historicamente.

Nosso esforço para conceber o discurso em torno da política nacional de EAD como remetendo à formação discursiva industrialização do ensino não ignora, evidentemente, sua capacidade de interagir com outras formações discursivas. Mesmo porque a identidade de uma formação define-se, também, pela rejeição de algumas unidades

10 A paráfrase, que trata de uma relação entre enunciados equivalentes e que pode levar à reformulação de um pelo outro, representa um dos fragmentos mais recorrentes evocados pelos textos. "Assim como a reformulação, a paráfrase é o vetor pelo qual se marca a heterogeneidade no discurso, seja ela mostrada ou constitutiva." (CHARAUDEAU; MAINGUENEAU, 2006, p.366) Outras figuras de linguagem que, também, aparecem demarcando os textos são a metáfora (que designa um referente por intermédio de um signo distinto daquele usualmente utilizado) e a metonímia (que mantém com o signo uma relação, como aquela da parte pelo todo), as quais representam a "presença da historicidade na língua." (ORLANDI, 2002, p.67) 
de sentido ("negativas") e projeção de outras ("positivas"), construídas nas formações com as quais estabelece relação. Para resguardar sua própria identidade, define Maingueneau (1993, p.122), o discurso apenas consegue "relacionar-se com o Outro do espaço discursivo através do simulacro que dele constrói. Chamaremos discurso agente aquele que se encontra em posição de 'tradutor', de construtor do simulacro, e discurso paciente aquele que desta forma é traduzido."

Além disso, tudo indica ser importante adotarmos procedimento talvez próximo ao que preocupou Foucault, a partir dos anos 1970, quando devota suas análises à relação existente entre os grandes tipos de discurso e as condições sócio-históricas de seu aparecimento e formação, marcando assim "a passagem metodológica da arqueologia à genealogia" (REVEL, 2005, p.38). Uma das pretensões da arqueologia, preconizava o próprio Foucault (2002, p.186), é evidenciar as relações entre as formações discursivas e não discursivas, determinando até que ponto as regras de formação que regem os enunciados vinculam-se a sistemas não discursivos, entre os quais os processos econômicos, os fatos e as instituições políticas. Em entrevista a Rouanet e Merquior (1971, p.24), o autor chamava atenção que essas relações no entanto seriam bem mais complexas do que a pura e simples expressão do que denominava das formas econômicas e sociais pré-discursivas, muito embora todas as regras que definiam os objetos, as posições do sujeito e a forma dos conceitos originavam-se de tais formações: "É somente a partir dessas regras que se poderá chegar ao estado terminal do discurso, que não exprime, portanto, essas condições, ainda que estas o determinem." (ROUANET; MERQUIOR, 1971, p.24) 
O dispositivo analítico acima descrito tenta seguir nessa direção, muito embora não ignoremos que poderá correr alguns riscos. Em primeiro lugar, o risco de envolvimento não só com a análise, como também com a construção do corpus, pode abrir o texto para o contexto no qual trabalhamos enquanto pesquisadores. Em segundo lugar, o risco de esbarrar no fato de que as condições de produção do discurso, em que pese sua importância para a construção do corpus de estudo, podem se tornar orientações teóricas capazes de condicionar o processo de compreensão. Inspirada na acepção marxista de condições econômicas de produção, a noção de condições de produção do discurso teria estabelecido uma correlação fortemente mecanicista entre discurso e classes sociais. "Em uma perspectiva que deve muito a Foucault, ela cedeu a vez a uma visão mais complexa das instituições discursivas e da relação entre o interior e o exterior do discurso" (CHARAUDEAU; MAINGUENEAU, 2006, p.114).

Por último, correríamos o risco de superestimar o papel das formações sociais e ideológicas, perdendo de vista a capacidade de renovação do discurso. A estratégia para evitar incorrer nesses e eventuais outros riscos, sugerem Charaudeau e Maingueneau (2006, p.142), será enfatizar o discurso como acontecimento, cuja compreensão se dá nos marcos do próprio "corpus e não fora dele". Na Análise de Discurso, salienta Cazarin (2005), é consenso o fato de que a própria formação discursiva "não é algo delimitado a priori porque se 'constrói' e se configura como gesto de interpretação." O que implica reconhecermos que a confirmação da pressuposição de que o discurso da industrialização do ensino refere a formação discursiva predominante na política nacional de educação a distância dependerá, também, de nosso gesto de compreensão. 